\title{
Land Reform System and Its Implications on Agricultural Production in Nigeria
}

\author{
Nzeh Emeka*, Famobuwa, O. S, Iroechenwu Chinemeze \\ Department of Agricultural Economics \& Extension, Enugu State University of Science and Technology (ESUT), Nigeria
}

Copyright $(2017$ by authors, all rights reserved. Authors agree that this article remains permanently open access under the terms of the Creative Commons Attribution License 4.0 International License

\begin{abstract}
This study is focused on assessing the implications of land reforms system on agricultural production in Nigeria. The study set three major objectives which include to: provide an overview of land reforms, examine the problems of land reforms and finally, consider the implication of land reforms on agricultural production in Nigeria. Land reform is usually linked with agricultural and rural development. This is so because the bulk of the population especially those involved in primary production depend on the availability of land in whatever form it may be required. Land must be available to persons and/or groups of people who are ready to put it to productive use. It is the farmers' most important asset and it plays an essential role in sustaining agricultural production. However, ownership of land often interferes with its use as an agricultural asset. The employment of land use reform is therefore needed to ensure equitable allocation, availability and distribution of land to ready users both in rural and urban areas of the country. The Nigeria Land Use Act need be revisited to make room for easy and efficient land access to individuals, corporate institution and their likes that would be ready to use land for productive purposes.
\end{abstract}

Keywords Agriculture, Agricultural Production, Land Reform, Land Tenure, Land Use Act

\section{Introduction}

In Nigeria, land is considered to underpin all social, economic and political development of a person or a household. Therefore, access to land also defines one's inclusion (or exclusion) in social, economic and political processes. There has been a plethora of literature on the nexus between land ownership and access to opportunities in social, political and economic spheres. Lack of access to land is linked to social exclusion [3]. In the agrarian economy, land is central to income and livelihood. Lack of income and livelihood opportunities and continuous work on low wages have made landless people not able to take part in the social and political processes within the community or at larger levels. This critical reduce the contribution of these households toward agricultural production in their areas. Access to land is also essential to enable rural poor to have equal opportunities created by market. Their access to land will make them able to take some of these opportunities created by the market.

Land and the institutions that govern its ownership and use greatly affect economic growth. Lack of access to land and inefficient or corrupt systems of land administration have a negative impact on agriculture especially in a developing country like Nigeria. Access to even small plots of land to grow crops can also greatly improve food security and quality. Policies that foster lease markets for land can also contribute to the emergence of a vibrant non-farm economy [3]. Improving land administration may also contribute to broader public service reform and provide a basis for wider reforms. Tenure rights to resources play a fundamental role in governing the patterns of natural resource management, as well as in the welfare of individuals and communities dependent on those resources [3].

In the words of the World Bank, land reform is "concerned with changing the institutional structure governing man's relationship with the land, involving intervention in the prevailing pattern of land ownership, control and usage in order to change the structure of holdings, improve land productivity and broaden the distribution of benefits" [13]. Parsons [9] defines land reform as the aggregate of ideas and courses of action designed to resolve tenure problems. His viewpoint is generally in line with the one expressed by the World Bank. It may consist of government initiated or government backed approach to property redistribution of land or as in the case of Nigeria, an outright transfer of ownership of land from the citizens to the state. The common characteristic of land reform is usually the modification or replacement of existing institutional arrangement governing possession, use and title. Thus, while land reform may be radical in nature such as large scale confiscation and transfers of land from one party to another or to the state, it can also be less drastic and conciliatory in nature such as regulatory reforms aimed at improving land administration 
[4].

\subsection{Problem Statement}

The land use pattern in Nigeria estimated arable land to be about $33 \%$ of the total land area, permanent pastures cover $44 \%$, permanent crops cover $3 \%$, forests and woodlands $12 \%$ and others $8 \%$ [12]. Thus land is still the main asset of rural Nigerians where over $80 \%$ are peasant farmers; however this asset has not been fully utilized for agricultural production [1]. Public investments in agriculture have been extremely low (less than $2 \%$ of total federal expenditure between 2001 and 2005), and corruption has been identified in areas where the federal and state governments have played a role (e.g., fertilizer distribution) [12]. Pressures have been growing, however, for the federal government to revitalize agriculture as well as to deal with the continuing political, social, and economic instabilities. Responding to these pressures is likely to require both the federal and state governments to consider reform of their positions on resource governance and the ability of citizens to access productive land and acquire secure rights to that land.

According to [12], most observers believe that not only have the objectives of the Land Use Act not been achieved, but that the law has contributed to further distortions and abuses of citizens' rights to access and own land. Further, government's land-use administration has not constrained the unrelenting expansion of agricultural land into fallow and forested areas or the overuse of forest resources to meet the population's energy and food needs.

\subsection{Objectives of the Study}

The general objective of this study is to assess the implication of land reform system on agricultural production in Nigeria. The specific objectives are to provide an overview on land reforms in Nigeria; examine the problems of land reforms in Nigeria and consider the implications of land reforms on agricultural production in the country.

\section{The Nigeria Land Use Act}

The current law guiding land administration in Nigeria is the Land Use Act, Cap L5, 2004, originally promulgated in 1978 [3]. It has however generated a lot of clamour for its review to make it more relevant to the needs of the present day. Until the introduction of the Land Use Act in 1978, the Crown Lands Law was adopted for the management and administration of land in the then Western, Mid-Western and Eastern Regions (when the country had Regional Governments). The provisions of the variants of the Crown Lands Act were substantially similar though it did not cover the administration of freeholds lands in those regions. They however differed significantly from the law governing the management of lands comprised in the then Northern Region, where the Colonial Administration nationalized land, divesting the Emirs who held the land in trust for the citizens [3].

The nationalization was consolidated by the Land and Native Rights Proclamation of 1914 , which was later replaced with the land Tenure Law of 1962 [3]. Thus, while the State Land Law of the Southern regions applied only to State lands, the Land Tenure Law of 1962 applied to all lands in the Northern region. The major difference between the laws in the South and North was the fact that freehold was possible in the South while only leasehold applied in the North. However, the land registration law applied equally to the Regions. The unfortunate implication was that different laws governed tenurial system to Nigeria while a single law governed land registration.

Furthermore, the laws, especially with regards to the North, were not quite in accord with the original culture and tradition of the people. Like experienced by other African countries in the hands of their colonial masters, they created new land rights over the existing rights of the indigenous population. The Land Use Act was an effort at solving the multiple land tenure system that existed in the country. The expectation was that it would make land acquisition easier so that a larger number of citizens would have access to land. The Act which essentially adopted the Land Tenure Law of Northern Nigeria to nationalize all land in Nigeria vested all lands comprised within the territory of a state in the Governor of that state (except lands vested in the Federal Government). By transferring the radical title of non-state land to the Governor, the Act sought to introduce a uniform land tenure system throughout the country.

According to [12], the objectives of the Land Use Act were to:

(1) make land accessible to all Nigerians;

(2) prevent speculative purchases of communal land;

(3) streamline and simplify the management and ownership of land;

(4) make land available to governments at all levels for development; and

(5) provide a system of government administration of rights that would improve tenure security.

The controversy that has trailed the Act explains how poorly it has addressed the land administration problems in Nigeria. There is a persistent clamour for its review and indeed it has not been reviewed for the nearly forty years that it has operated. One major factor hindering its review is the fact that it is entrenched in the 1999 constitution of the country making it difficult to isolate for review [12].

As extracted from [10] Land Use Act (1978), seven of the more important provisions of that decree are indicated below:

1. All land situated in the territory of each state of the country is vested upon the governor of the state. For southern Nigeria in particular, this means state appropriation of land from families and communities without any compensation except for economic crops 
and other betterment on the land.

2. All land control and management, including land allocation in urban areas come under the Governor of each state while land located in rural areas becomes the responsibility of the various local governments. Only the governor can declare parts of the state territory governed by him as an urban area by an order published in the state gazette.

3. All land in urban areas is to be administered by a body known as the Land Use and Allocation Committee which has the responsibility of advising the Governor on the management of urban land. Similarly, a Land Allocation Advisory Committee is provided to advise local governments in like manner.

4. All land which has already been developed remains in possession of the person in whom it was vested before the Act became effective.

5. The Governor is empowered to grant Statutory Certificate of Occupancy (C of O) which would be for a definite term to any person for all purposes and rights of access to land under his control.

6. The maximum area of undeveloped land that any person could hold in any one urban area in a state is one half of a hectare; in the rural areas, this must not exceed 500 hectares except with the permission of the governor.

7. The consent of the Governor must be secured for the transfer of a statutory right of occupancy through either mortgage or assignment. The consent of the local government or that of the Governor in appropriate cases must also be obtained for the transfer of customary right of occupancy.

The Land Use Act has never been fully implemented. Most citizens, especially most rural citizens, are unaware of the Act and few have applied for certificates of occupancy. In many areas, the Land Allocation Advisory Committees are reportedly not functioning, and the rural populations continue to look to their chiefs and emirs on matters relating to land. The chieftaincy or emirate (in northern Islamic states) is responsible for managing the community land, making allotments to individuals and households, establishing the areas of communal land (e.g., washing areas, grazing land, market sites), setting rules regarding communal land and its resources (and in some circumstances, the use of land allotted to individuals), and adjudicating land disputes. Even in urban areas, where the majority of the population lives in informal settlements, customary and Sharia' law govern rights and obligations relating to land [8].

\subsection{Problems of the Land Use Act}

Although the decree has made it easy for governments to acquire land for public purposes, drastically minimised the burden of land compensation and considerably reduced court litigations over land, it has since its inception created a new genre of serious problems for land management in the country [6]. Most of the problems with the Land Use Act border more on the implementation procedure rather than the provisions themselves; however the following problems with the provisions are pertinent.

The lack of prerequisite maps for determining who owns what land; the non-explicit demarcation of urban and rural areas, and the assumption that the prerequisite national cadastre and geospatial data infrastructure, which are very essential for any land tenure reform, were available [1]. The exclusion by the decree of the rights of families or individuals to develop private lay-outs has led to the emergence of a disjointed, uncoordinated and incoherent system of physical planning in Nigerian cities and a declining rate of housing provision and even agricultural production in the country.

Each succeeding Federal Government since the promulgation of the Act had exhibited lack of political will to implement various provisions of the Act to make it succeed. The Act made allowance for transitional provisions for the orderly assimilation of the land tenure systems it hoped to replace, but 30 years, after these other land tenure systems are still being operated [1]. Many state governments failed to establish the Land Use and Allocation committee in their states for many years. This has hampered the steady and continuous delivery of land for building purposes.

The operation of the land Use Act by its "trustees" - the State Governors and local government Chairmen had been characterized by its use as political weapon, lack of transparency, arbitrary and selective administration of its provisions [1]. The power of governors and local government chairmen to revoke any right of occupancy over land 'for overriding public interest' has been used arbitrarily in the past and helps to underscore the fragility of the rights conferred by the certificate. In consequence, there is increasing reluctance by both the courts and the banks to accept the Statutory Certificate of Occupancy neither as a conclusive evidence of the title of the holder to the land nor as adequate security in an application for loan.

Equally serious is the fact that some governors use the provision requiring their consent for assignments or mortgaging as a means of raising revenue for their states through imposition of heavy charges for granting such consent. Thereby making the process of obtaining title to land is expensive and tedious. It is antithesis to a dynamic market land economy. Also many governors do not give the urgent attention needed to their responsibility of granting consent for land assignments thereby impeding the development of an efficient land market and housing. The inconveniences and delays in securing Statutory certificates of occupancy have induced many land transactions among Nigerians to move to the informal market or be falsely dated as having been concluded before March 28, 1978; the operative date for the Land Use Decree. Consequently, 30 years after its operation less than $3 \%$ of land in the country, mainly in the urban areas, is covered by title deeds [8]; [5]; [2]; [1]. 
The Act has not succeeded in removing the uncertainties in title to land; instead, it seems to accentuate it. It does not protect small scale peasant farmers who continually lose their farm lands through acquisition for urban expansion and large-scale acquisition of land for commercial agriculture, most of which are speculative, without paying adequate compensation [1] As of 2006, roughly 2 million people had lost their homes and land to compulsory land acquisitions [12]. The government's use of its acquisition power is subject to increasing challenge - both by residents resisting eviction and by organizations questioning the -public purpose in taking land from one set of private parties to give to another set [7].

The philosophy of the Act, that all land belongs to the state; all undeveloped land has no value and hence has no market value; and that there is no freehold of land deterred the development of market land economy in Nigeria. The decree as it stands represents an abrogation of the right of ownership of land hitherto enjoyed by Nigerians, at least in the southern half of the country, and its nationalization by the government is inconsistent with democratic practices and the operations of a free market economic system. The Act abolished the existing freehold title to land and limits the title that can be granted under it to leasehold interests not exceeding 99 years [1]. Thus under the act all allottees of state land and owners of properties covered by a Certificate of Occupancy became tenants of the State.

\section{Need for Land Reform in Nigeria}

The inadequacies of the current land tenure system as embodied in the Land Use Act, informed the agitation for its review by many stakeholders. Apart from the need to overhaul the land tenure system, government was made to realise that there could be no true development without the economic empowerment of the rural dwellers through the conversion of their natural asset, land, to capital by granting them titles to their land holding and creating an open land market economy (Atilola, 2010).

According to Mabogunje (2007), the importance of the State taking a firm hand with respect to land reform can thus not be underestimated. Defined land ownership whether of a leasehold or freehold type is crucial for promoting the capabilities of rural producers, enhancing their access to credit, enabling them to invest in farm infrastructure and improved input, and generally improving their productivity. Without it all talks of poverty eradication and hunger alleviation especially at the rural end is at best no more than fighting the symptoms rather than causes of poverty [6].

Thus land is a natural asset of the common man which government should help in converting to capital and means of empowerment. At present this natural asset of majority of rural Nigerians is locked up as "dead capital" as various interests in them does not possess titles to raise capital. Only about $3 \%$ of the land in Nigeria is covered by title deeds [3].
It is this low level of land titling that accounts for the high level of poverty in the land as it is not possible to harness the potentials in land without title deeds. This made the use of land for agrarian activities reduced and thereby leading to reduction in the agricultural production and even its productivity in the recent time.

The philosophy of the Land Use Act that all land belongs to the state and should be held in trust by the governor for the people., and that undeveloped land has no value, constitute a great obstacle to the development of a dynamic market land economy. Therefore, needs a surgical review for the current initiatives of unlocking the commercial potentials of land in Nigeria to be realised. It is the current dysfunctional nature of land administration dynamics in Nigeria, and concerns arising from its unproductive nature, that informed the need to provide a better strategy that will make Land Administration work and also provide benefits to all citizens of Nigeria. The other problems are operational and bureaucratic issues, including lack of institutional, administrative, infrastructural and professional expertise for the operations, which negatively affect the effectiveness of the law.

Furthermore, a minimum limit could also be fixed and farmers encouraged and assisted to cultivate enough land to meet the subsistence and non-farm needs of their families and provide a sellable surplus to meet the needs of urban population. To makes this possible, it may be important to undertake a cadastral survey and to explore the possibilities of colonizing unused arable land for the benefit of needy farmers. Experiences in other parts of the world demonstrate that you cannot guarantee equality of opportunity or prevent invidious class differentiation on in the farm sector, if you do not sufficiently restricts the size of individual holdings. Another fundamental problem with the Land Use Act lies in the fact that it has not taken the farm structure and landholding patterns and their implications for productivity and economic security into serious consideration. Its emphasis is on formal tenure, i.e. on the definition of the types of rights individuals and groups have relative to the state. It failed to address the problem of 'Lilliputian and fragmented holdings' which is prevalent in our farming system and the question of measures that can be taken to assist farmers to increase their resources base improve their productivity and incomes [3]. This is a key problem because the question of what use is made of the land is as significant as that of ownership. You cannot guarantee ownership of the land by the poor by merely preventing absolute individual ownership. This problem led to none production of so many permanent crops that will hence reduce poverty and increase agricultural production especially in a developing country like Nigeria.

For any land reform to become an important instrument for equalizing access to land, it must contain policies that can raise productivity and income of farmers [3]. For example, a fragmented and marginal holding which cannot provide adequate income or full time employment for farmers 
exposes them to the possibility of being forced to become landless and jobless. The existence of a free market in land and differentiation on the basis of wealth and social and economic power clearly indicates there is a strong possibility for greater disparity in landholding, welfare and performance and points to the enormity of the real and potential insecurity for the poor farmers. This will happen as farmers land get increasingly fragmented; if they continue to lack ability to produce enough from their land, and as they are exposed to increasing population pressure and greater commercialization of interests in land made possible largely by urban capital.

The results of this development could be very devastating as there seems to be a growing investment in agriculture on the part of those who get substantial income from the non-farm sector, more so as the majority of our farmers are caught in a cycle of poverty arising mostly from technical deficiencies, shortage of working capital and lack of access to improved technology that could make their effort profitable. Thus, by ignoring to plan simultaneously to tackle the problem of land use, the Act has indirectly exposed marginal farmers to the possibility of losing their only means for economic survival [3]. This is most likely because of a dismal shortage and mal-distribution of the supportive services that could make farming more profitable and secure.

According to [12], differing views as to the most effective methods of land tenure reform have been expressed. While some believe smallholder farmers should be allowed to expand in adjacent plots and otherwise consolidate their holdings to encourage mechanization and economies of scale, others solicit for the preservation of smallholdings and provision of smallholder farmers with appropriate technologies. Some have also expressed the need for tax landholdings to obligate farmers to increase their efficient utilization and bring large tracts of underutilized land into production or that lands that have been acquired in dubious fashion should be redistributed. Still others maintain that markets should replace the administrative allocation processes enshrined in the Land Use Act.

In 2007, Nigeria's past administration introduced a 7-Point Agenda, which included land reforms that optimized economic growth through the release of state land for commercialized farming and other large-scale businesses operated by the private sector, [12]. In any case, in it was stated that National Assembly rejected bill to establish a National Land Reform Commission for the restructuring of land matters across the country [12] by the then government in 2010 .

Following this development, a Presidential Technical Committee on Land Reform was formed to advise the government on the creation of a national cadastre, a plan for registration of landholdings, and the development of mechanisms for land valuation and conflict resolution. The land reform committee in Nigeria is aimed towards enabling the state to be effective managers of land. It is aimed to provide a systematic cadastral survey of land in the entire federation the term of reference makes it an essential body to assist both states and local government to carry out cadastre survey and codify the possessory right of the majority of the people access to land and landowners. The term of reference necessitate the body to collaborate and provide technical assistance to the states and local governments in undertaking cadastral survey and to ensure the demarcation of land boundaries and title holdings in such a way that communities, hamlets, villages and towns are recognized it was also saddled with the responsibility of encouraging state and local governments to establish adjudication mechanism for land ownership, conflict resolution and to make recommendation for mechanism for valuation in both rural and urban areas.

\section{Summary, Conclusions and Recommendations}

Land is the farmers' most important asset and it plays an essential role in agricultural production. Ownership of land however, often interferes with its use as an agricultural asset. The employment of land reform is therefore needed to ensure equitable allocation, availability and distribution. The Land Use Act was promulgated in 1978 with the objective of making land accessible to all Nigerians. However, it can be said that this objective has not been realised probably as a result of the numerous problems associated with the Act. For any land reform to be effective, it must contain policies that can raise the productivity and income of farmers. The inadequacies of the current land reform system as embodied in the Land Use Act have called for its review by stakeholders.

Land is important to the life of man. Land is wealth, prestige and power. It is important for poverty reduction and food security. Its availability ensures economic development and growth. For agriculture to develop; land must be readily available - reform is one vehicle that ensures availability and access to land. Land tenure reform measures taken by the state empowers its citizens to realize their potentials in the development process.

After careful observation of the current situation of the country's land reform system, this study recommends that; the masses should be educated about the reform objectives, laws and procedures and the relationship between the state and local governments and the farmers should be further strengthened to increase the access to land for agricultural purposes. The possibilities of colonizing unused arable land for the benefit of needy farmers should be explored.

\section{REFERENCES}

[1] Atilola, O. (2010). Land Administration Reform in Nigeria: Paper presented at FIG congress held in Sydney, Australia.

[2] Butler, S.B. (2009). Improving Land Policy for Private Sector 
Development in Nigeria: Lessons and Challenges Ahead. Paper presented at the World Bank Conference on Land Governance in support of the MDGs, 9-10 March, Washington, DC.

[3] Chikaire, J.U., Anyoha, N.O., Ani, A.O., and Atoma, C.N. (2014). Land tenure reform: A vehicle for achieving agricultural transformation agenda in Nigeria. Merit Research Journal of Agricultural Science and Soil Sciences (ISSN: 2350-2274) Vol. 2(9):114-122, September, 2014.

[4] Dada, Akinpelu. (2010). How Land Use Act Impedes Socio-Economic Development. Journal of Economics and Rural Development, 15(1); 12-15

[5] Dale P. (2007). Good Land Administration- Its Role in the Economic Development. Keynote Speech on Land Administration in Transition. International Workshop, Ulaanbaatar, Mongolia.

[6] Mabogunje, A.L. (2007). Land reform in Nigeria: Progress, Problems and Prospects. Chairman Presidential Technical Committee for Land Reform.

[7] Nuhu, Muhammad. (2007). Compulsory Acquisition and Payment of Compensation in Nigeria: A Case Study of FCT
Abuja. A presentation prepared for FIG Workshop on Compulsory Purchase and Compensation, 6-8 September, Espoo, Finland.

[8] Olayiwola, L. and Adeleye, O. (2006). Land Reform Experience form Nigeria. Paper presented at the FIG Regional Conference Promoting Land Administration and Good Governance, 8-11 March, Accra, Ghana.

[9] Parsons, K.H., (1996). Land Reform and Agricultural Development. K.H. Parsons, K.J. Penn, and P.H. Raup (Eds) Land Tenure. Madison: University of Wisconsin Press.

[10] Republic of Nigeria (RON). (1978) Land Use Act. Retrieved from

$<$ http://www.nigeria-law.org/Land\%20Use\%20Act.htm>

[11] Ukaejiofor, A.N. (2008). Perspectives in Land Administration Reforms in Nigeria. J. Environ. Vol. 2 (1): 43 - 56.

[12] United States Agency for International Development (USAID) (n.d.). Nigeria - Property Rights and Resource Governance. USAID Country Profile.

[13] World Bank, (1996). Land Reform. World Band Paper - Rural Development Series, Washington, D.C. 